\title{
THE INFLUENCE OF SLOVENIAN TRAFFIC SAFETY AGENCY ON MOTOR VEHICLE LEGISLATION
}

\section{MSc Tomaž Svetina*}

Slovenian Traffic Safety Agency, Ljubljana, Slovenia

Ljubo Zajc

Slovenian Traffic Safety Agency, Ljubljana, Slovenia

Dr Vladimir Popović

University of Belgrade, Faculty of Mechanical Engineering, Belgrade, Serbia

The objective of this paper is to provide an analysis of the type-approval system in the Republic of Slovenia. In this analysis Slovenian legislation regarding motor vehicles is compared to EU legislation. Besides this the Slovenian Traffic Safety Agency's influence on the above mentioned legislation is presented, as well as the legislation's influence on safety and environmental friendliness.

Key words: Type approval, motor vehicle act, the Slovenian Traffic Safety Agency, periodical technical inspection

\section{INTRODUCTION}

The Slovenian Traffic Safety Agency was established to ensure traffic safety in the Republic of Slovenia. The Agency was founded on $1 \mathrm{Sep}$ tember 2010 [06]. It consists of four departments as shown on Figure 1:
- Department of Motor Vehicles;

- Department of Drivers;

- Department of Analysis, Development and Communication;

- Council for Prevention and Road Safety.

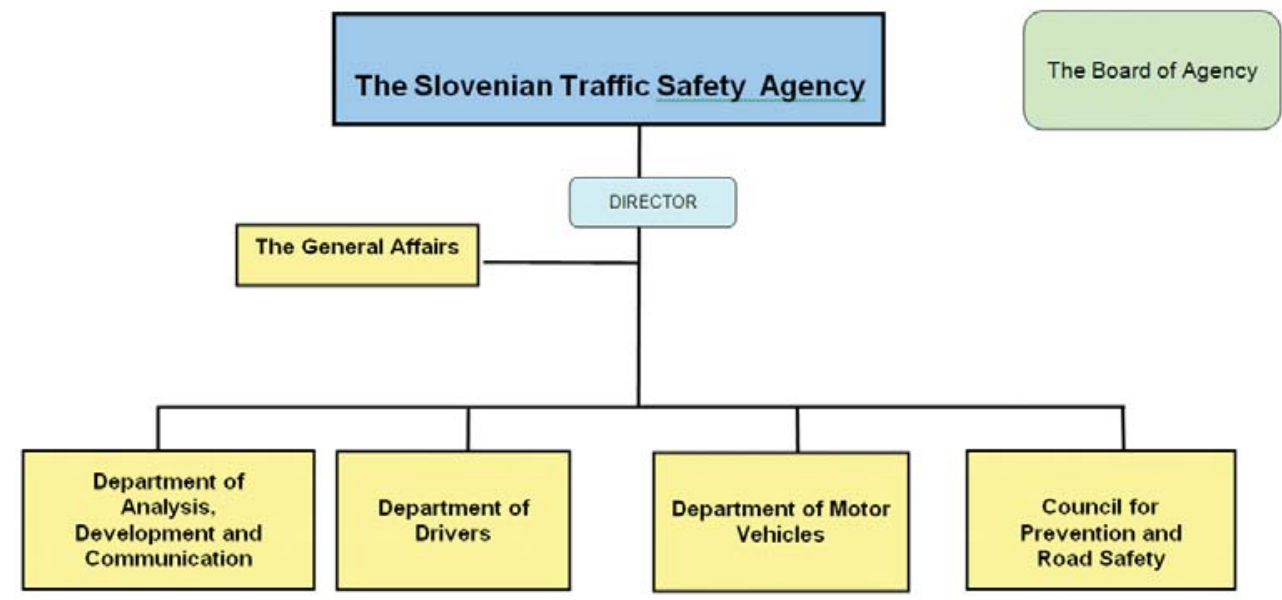

Figure 1: Organization of the Slovenian Traffic Safety Agency

At the moment the Agency covers all types of road transport. The Vehicle Department deals with homologation [04], periodical technical inspections and registration of vehicles.

It performs the following tasks:

- different type approval procedures;

- certifications of systems, components and separate technical units;
- collecting data of vehicles which are imported to Slovenia;

- registration of vehicles;

- periodical technical inspection of vehicles;

- professional supervision over the work of registration organizations;

- professional supervision over the work of organizations performing PTI-s. 


\section{THE MISSION OF THE SLOVENIAN TRAFFIC SAFETY AGENCY}

Figure 2 shows the Internet site of the Slovenian Traffic Safety Agency. The Agency's mission is to provide highest level of safety and to reduce the number of worst consequences of accidents (fatalities and injuries) on Slovenian roads.
The Agency carries out different activities in order to enable Slovenia to become one of the three most successful European countries regarding traffic safety. These activities comprise campaigns against speed violation, campaigns against drinking and driving, motor vehicle safety, prevention campaigns ...

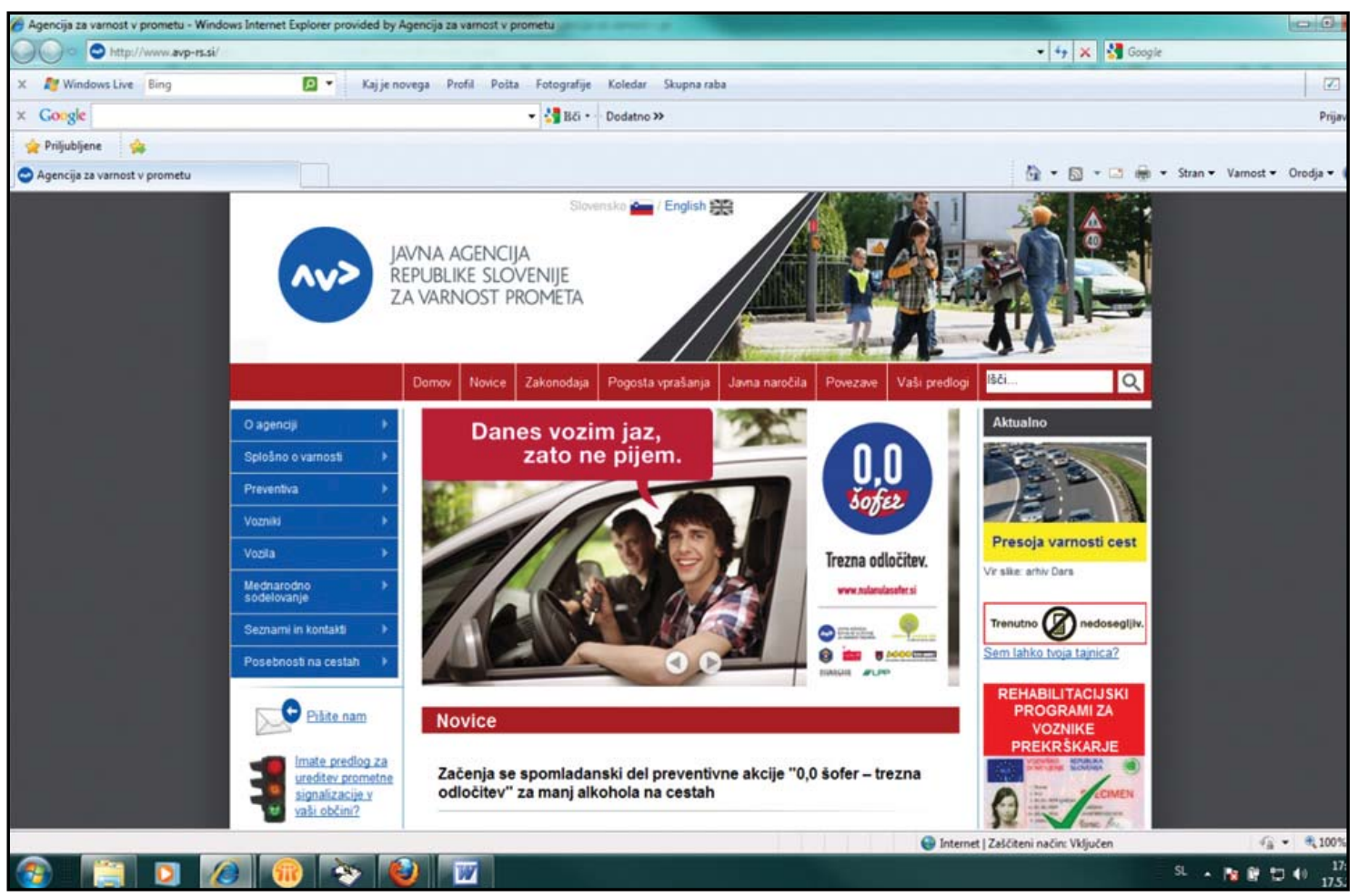

Figure 2: Slovenia Traffic Safety Agency on the internet

Campaigns against speed violation and drinking and driving are overseen by the Department of Analysis, Research and Communication whereas activities regarding motor vehicle safety are coordinated by the Department of Motor Vehicles, and activities regarding prevention are supervised by the Council for Prevention and Road Safety. In this regard it is important that all departments involved in carrying out these activities cooperate tightly to achieve the best possible results. In the past the area of traffic safety was neglected. As a result of this Slovenia is still not among the most successful European countries in this area. Our goal is to improve the overall situation regarding traffic safety.

\section{TASKS OF THE DEPARTMENT OF MOTOR VEHICLES}

In Slovenia there are more then 80 organizations appointed to implement technical inspection procedures, more then 120 organizations appointed to provide registration procedures and more then 60 organizations to provide individual approval procedures. The exact number of organizations is changing all the time. The Slovenian Traffic Safety Agency delegates authorizations for different organizations. The conditions are set out in national legislation, and all organizations carrying out procedures of individual approval [3], registration or technical inspection must fulfill these conditions. Some of these conditions are: sufficient expert knowledge, sufficient number of qualified personnel, suitable equipment [10], etc.

Upon its accession to the EU on 1 May 2004, Slovenia harmonized its national legislation with EU legislation. The Department of Motor Vehicles carries out different procedures which are set out in national legislation [10]. Three important directives issued by the European Parliament in this area are: 2007/46/EC which covers motor vehicles [03], 2002/24/EC relating to the type-approval of two or three-wheel motor ve- 
hicles [02] and 2003/37/EC on type-approval of agricultural or forestry tractors, their trailers and interchangeable towed machinery, together with their systems, components and separate technical units [07]. All European requirements are implemented in Slovenian legislation by technical specifications of the vehicles [05].

The European certificate in accordance with European regulations can be issued in case that vehicle systems, components and separate technical units are tested by technical organizations appointed, and if the testing procedure was carried out in accordance with all necessary requirements [10]. Then the Slovenian type approval authority - the Slovenian Traffic Safety Agency certifies the systems, components or separate technical units [04]. After issuing the certificate the Slovenian Traffic Safety Agency has to ensure conformity of production of such systems, components or separate technical units [04].

The end of series vehicles can be put in service after legislation has been changed in case that the manufacturer can prove that they were produced before the change in legislation [01]. So the type approval authority can allow the manufacturer to put a limited number of vehicles in service although they might not fulfill all requirements. The period of end of series is 12 months for finished vehicles. In Slovenian legislation there is also a definition of veteran vehicles. This is a national definition which sets the age limit for veteran vehicles at 30 years, and such vehicles must fulfill separate requirements for veteran vehicles, e.g. the vehicle has to comply with the original design and shape. For veteran vehicles it is necessary. Every vehicle intended to become a veteran vehicle has to be inspected separately in accordance with the requirements set out in national legislation. The procedure must be carried out by an organization appointed by the Slovenian Traffic Safety Agency. Veteran vehicles must not be used for everyday purpose. To control the use of veteran vehicles special registration plates for veteran vehicles have been introduced.

Vehicles owned by people who worked abroad and decided to return can be imported without any approval requirements if the owner was abroad for more than one year and if he/she has been the owner of the vehicle for more than half a year. Such a vehicle can be imported within 12 months, with adjustments regarding headlamps, orange indicators and speedometer (metric units).
For the Department of Motor Vehicles a good IT support is necessary. This can ensure technical data of the vehicles which are forwarded to registration organizations. The Slovenian Traffic Safety Agency is in charge of collecting all technical data regarding types, variants, versions. After adding vehicle identification number (VIN), color and date of issuing national $\mathrm{COC}$, all necessary data for a particular vehicle are collected. Before issuing a paper version, all necessary data has to be entered into the IT system. The paper version is printed on pre-printing forms which are numbered and submitted to organizations issuing the COC. A good IT system helps to trace the history of the documentation of certain vehicles in their life cycle.

The Slovenian Traffic Safety Agency performs professional supervision over registration organizations, organizations which carry out periodical technical inspections and organizations which carry out approvals. Due to this the Slovenian Traffic Safety Agency has closer contacts with the above mentioned organizations than the Ministry of Infrastructure and Spatial Planning which is in charge of legislation in this area. The Slovenian Traffic Safety Agency has the possibility to influence the content of certain laws and regulations in case that some definitions might not be harmonized. The Slovenian Traffic Safety Agency organizes meetings and workshops for registration organizations, periodical technical inspections organizations and organizations which carry out type approvals. At such meeting the Slovenian Traffic Safety Agency collects suggestions and comments on the problems which arise during work, and it influences laws and regulations.

\section{LEGISLATION DEALING WITH VEHICLE}

Slovenian legislation dealing with vehicles in accordance with European legislation. We have an act on motor vehicles and three regulations for different categories of vehicles:

- motor vehicles [03],

- two and three wheel vehicles [02] and

- agricultural and forest tractors [07].

All legislation is in accordance with European legislation. We have technical specifications for different parts, systems and technical units of vehicles as is shown in the Table 1. 
Table 1: The list of regulatory acts

\begin{tabular}{|c|c|c|c|c|c|c|c|c|c|c|c|c|c|}
\hline & Subject & Directive & Regulation & M1 & M2 & M3 & N1 & N2 & N3 & 01 & 02 & 03 & 04 \\
\hline 1 & Sound levels & 70/157/EEC & ECE R 51 & $x$ & $x$ & $x$ & $x$ & $x$ & $\mathrm{X}$ & & & & \\
\hline 2 & Emissions & $\begin{array}{l}\text { 70/220/EEC, } \\
715 / 2007\end{array}$ & ECE R 83 & $x$ & $x$ & $\mathrm{X}$ & $\mathrm{X}$ & $x$ & $\mathrm{X}$ & & & & \\
\hline 3 & $\begin{array}{l}\text { Fuel tanks / } \\
\text { rear protective } \\
\text { devices }\end{array}$ & 70/221/EEC & $\begin{array}{l}\text { ECE R 34, } \\
\text { ECE R 67, } \\
\text { ECE R } 110\end{array}$ & $x$ & $x$ & $\mathrm{X}$ & $x$ & $x$ & $\mathrm{X}$ & $\mathrm{X}$ & $X$ & $x$ & $x$ \\
\hline 4 & $\begin{array}{l}\text { Rear registration } \\
\text { plate space }\end{array}$ & 70/222/EEC & - & $x$ & $x$ & $\mathrm{X}$ & $X$ & $\mathrm{X}$ & $\mathrm{X}$ & $\mathrm{X}$ & $\mathrm{X}$ & $x$ & $x$ \\
\hline 5 & Steering effort & 70/311/EEC & ECE R 79 & $x$ & $x$ & $x$ & $x$ & $x$ & $x$ & $x$ & $x$ & $x$ & $x$ \\
\hline 6 & $\begin{array}{l}\text { Door latches } \\
\text { and hinges }\end{array}$ & 70/387/EEC & $\begin{array}{l}\text { ECE R 11, } \\
\text { GTR br.1 }\end{array}$ & $x$ & & & $X$ & $x$ & $\mathrm{X}$ & & & & \\
\hline 7 & Audible warning & 70/388/EEC & ECE R 28 & $x$ & $x$ & $x$ & $x$ & $x$ & $x$ & & & & \\
\hline 8 & $\begin{array}{l}\text { Devices for } \\
\text { indirect vision }\end{array}$ & 71/127/EC & ECE R 46 & $x$ & $x$ & $x$ & $X$ & $x$ & $X$ & & & & \\
\hline 9 & Braking & 71/320/EEC & $\begin{array}{c}\text { ECE R 13, } \\
\text { ECE R 13H, } \\
\text { ECE R 90, } \\
\text { GTR br. } 8 \text { (za ESC) }\end{array}$ & $x$ & $x$ & $x$ & $x$ & $x$ & $\mathrm{X}$ & $X$ & $X$ & $x$ & $x$ \\
\hline 10 & $\begin{array}{l}\text { Suppression } \\
\text { (radio) }\end{array}$ & 72/245/EEC & ECE R 10 & $x$ & $x$ & $x$ & $x$ & $x$ & $x$ & $x$ & $\mathrm{X}$ & $x$ & $x$ \\
\hline 11 & Diesel smoke & 72/306/EEC & ECE R 24 & $x$ & $x$ & $x$ & $X$ & $x$ & $\mathrm{X}$ & & & & \\
\hline 12 & Interior fittings & 74/60/EEC & ECE R 21 & $x$ & & & & & & & & & \\
\hline 13 & $\begin{array}{l}\text { Anti-theft and } \\
\text { immobiliser }\end{array}$ & 74/61/EEC & $\begin{array}{l}\text { ECE R 18, } \\
\text { ECE R } 97\end{array}$ & $x$ & $x$ & $x$ & $X$ & $x$ & $x$ & & & & \\
\hline 14 & $\begin{array}{l}\text { Protective } \\
\text { steering }\end{array}$ & 74/297/EEC & ECE R 12 & $x$ & & & & $x$ & & & & & \\
\hline 15 & Seat strength & 74/408/EEC & $\begin{array}{l}\text { ECE R 17, } \\
\text { ECE R } 80\end{array}$ & $x$ & $x$ & $x$ & $x$ & $\mathrm{X}$ & $\mathrm{X}$ & & & & \\
\hline 16 & $\begin{array}{l}\text { Exterior } \\
\text { projections }\end{array}$ & 74/483/EEC & ECE R 26 & $x$ & & & & & & & & & \\
\hline 17 & $\begin{array}{l}\text { Speedometer } \\
\text { and reverse gear }\end{array}$ & 75/443/EEC & ECE R 39 & $x$ & $x$ & $x$ & $\mathrm{X}$ & $x$ & $\mathrm{x}$ & & & & \\
\hline 18 & $\begin{array}{l}\text { Plates } \\
\text { (statutory) }\end{array}$ & 76/114/EEC & - & $x$ & $x$ & $x$ & $\mathrm{X}$ & $x$ & $\mathrm{X}$ & $\mathrm{X}$ & $x$ & $\mathrm{x}$ & $x$ \\
\hline 19 & $\begin{array}{c}\text { Seat belt } \\
\text { anchorages }\end{array}$ & 76/115/EEC & ECE R 14 & $x$ & $x$ & $x$ & $x$ & $x$ & $x$ & & & & \\
\hline 20 & $\begin{array}{l}\text { Installation of } \\
\text { lighting } \\
\text { and light } \\
\text { signalling } \\
\text { devices }\end{array}$ & 76/756/EEC & ECE R 48 & $x$ & $x$ & $x$ & $x$ & $x$ & $\mathrm{X}$ & $x$ & $x$ & $x$ & $x$ \\
\hline 21 & $\begin{array}{l}\text { Retro } \\
\text { reflectors }\end{array}$ & 76/757/EEC & ECE R 3 & $x$ & $x$ & $x$ & $x$ & $x$ & $\mathrm{X}$ & $x$ & $x$ & $x$ & $x$ \\
\hline 22 & $\begin{array}{l}\text { End-outline, } \\
\text { front -side, } \\
\text { rear-side, stop, } \\
\text { day time running, } \\
\text { side-marker lamps }\end{array}$ & 76/758/EEC & $\begin{array}{l}\text { ECE R 7, } \\
\text { ECE R } 87, \\
\text { ECE R } 91\end{array}$ & $x$ & $x$ & $x$ & $\mathrm{X}$ & $x$ & $X$ & $\mathrm{X}$ & $x$ & $x$ & $x$ \\
\hline 23 & $\begin{array}{l}\text { Direction } \\
\text { indicators }\end{array}$ & 76/759/EEC & ECE R 6 & $x$ & $x$ & $x$ & $x$ & $x$ & $x$ & $x$ & $x$ & $x$ & $X$ \\
\hline
\end{tabular}




\begin{tabular}{|c|c|c|c|c|c|c|c|c|c|c|c|c|c|}
\hline 24 & $\begin{array}{l}\text { Rear registration } \\
\text { plate lamps }\end{array}$ & 76/760/EEC & ECE R 4 & $x$ & $x$ & $x$ & $x$ & $x$ & $x$ & $x$ & $x$ & $x$ & $x$ \\
\hline 25 & $\begin{array}{c}\text { Head lamps } \\
\text { (including bulbs) }\end{array}$ & 76/761/EEC & $\begin{array}{c}\text { ECE R 1, } \\
\text { ECE R 5, } \\
\text { ECE R 8, ECE R 20, } \\
\text { ECE R 31, } \\
\text { ECE R 37, } \\
\text { ECE R 98, } \\
\text { ECE R } 99\end{array}$ & $x$ & $\mathrm{x}$ & $x$ & $x$ & $x$ & $x$ & & & & \\
\hline 26 & Front fog lamps & 76/762/EEC & ECE R 19 & $x$ & $x$ & $x$ & $x$ & $x$ & $x$ & & & & \\
\hline 27 & Towing hooks & 77/389/EEC & - & $x$ & $x$ & $x$ & $x$ & $x$ & $x$ & & & & \\
\hline 28 & Rear fog lamps & 77/538/EEC & ECE R 38 & $x$ & $x$ & $x$ & $x$ & $x$ & $x$ & $x$ & $x$ & $x$ & $x$ \\
\hline 29 & Reversing lamps & 77/539/EEC & ECE R 23 & $x$ & $x$ & $x$ & $x$ & $x$ & $x$ & $x$ & $x$ & $x$ & $x$ \\
\hline 30 & Parking lamps & 77/540/EEC & ECE R 77 & $x$ & $x$ & $x$ & $x$ & $x$ & $x$ & & & & \\
\hline 31 & $\begin{array}{l}\text { Seat belts and } \\
\text { restraint systems }\end{array}$ & 77/541/EEC & $\begin{array}{l}\text { ECE R 16, ECE } \\
\text { R } 44\end{array}$ & $x$ & $x$ & $x$ & $x$ & $x$ & $x$ & & & & \\
\hline 32 & Forward vision & 77/649/EEC & - & $x$ & & & & & & & & & \\
\hline 33 & $\begin{array}{l}\text { Identification of } \\
\text { controls }\end{array}$ & 78/316/EEC & - & $x$ & $\mathrm{X}$ & $x$ & $x$ & $x$ & $x$ & & & & \\
\hline 34 & Defrost/demist & 78/317/EEC & - & $x$ & $x$ & $x$ & $x$ & $x$ & $x$ & & & & \\
\hline 35 & Wash/wipe & 78/318/EEC & - & $x$ & $x$ & $x$ & $x$ & $x$ & $x$ & & & & \\
\hline 36 & Heating systems & 2001/56/EC & - & $x$ & $x$ & $x$ & $x$ & $x$ & $x$ & $x$ & $x$ & $x$ & $x$ \\
\hline 37 & Wheel guards & 78/549/EEC & - & $x$ & & & & & & & & & \\
\hline 38 & Head restraints & 78/932/EEC & $\begin{array}{c}\text { ECE R 17, ECE R } \\
25, \text { GTR br. } 7\end{array}$ & $x$ & & & & & & & & & \\
\hline 39 & $\begin{array}{c}\mathrm{CO} 2 \\
\text { emissions/fuel } \\
\text { consumption }\end{array}$ & 80/1268/EEC & ECE R 101 & $x$ & & & & & & & & & \\
\hline 40 & Engine power & 80/1269/EEC & ECE R 85 & $x$ & $x$ & $x$ & $x$ & $x$ & $x$ & & & & \\
\hline 41 & Diesel emissions & 88/77/EEC & ECE R 49 & $x$ & $x$ & $x$ & $x$ & $x$ & $x$ & & & & \\
\hline 42 & Lateral protection & 89/297/EEC & ECE R 73 & & & & & $x$ & $x$ & & & $x$ & $x$ \\
\hline 43 & $\begin{array}{l}\text { Spray suppression } \\
\text { systems }\end{array}$ & 91/226/EEC & - & & & & & $x$ & $x$ & & & $x$ & $\mathrm{x}$ \\
\hline 44 & $\begin{array}{l}\text { Masses and di- } \\
\text { mensions (cars) }\end{array}$ & 92/21/EEC & - & $x$ & & & & & & & & & \\
\hline 45 & Safety glass & 92/22/EEC & $\begin{array}{l}\text { ECE R 43, GTR } \\
\text { br. } 6\end{array}$ & $x$ & $x$ & $x$ & $x$ & $x$ & $x$ & $x$ & $x$ & $x$ & $\mathrm{x}$ \\
\hline 46 & Tyres & 92/23/EEC & $\begin{array}{l}\text { ECE R 30, } \\
\text { ECE R 54, } \\
\text { ECE R } 64\end{array}$ & $x$ & $x$ & $x$ & $x$ & $x$ & $x$ & $x$ & $x$ & $x$ & $x$ \\
\hline 47 & Speed limiters & 92/24/EEC & ECE R 89 & & & $x$ & & $x$ & $x$ & & & & \\
\hline 48 & $\begin{array}{l}\text { Masses and } \\
\text { dimensions } \\
\text { (other than } \\
\text { vehicles } \\
\text { referred to in item } \\
\text { 44) }\end{array}$ & 97/27/EC & - & & $x$ & $x$ & $\mathrm{X}$ & $x$ & $x$ & $\mathrm{X}$ & $x$ & $x$ & $x$ \\
\hline 49 & $\begin{array}{l}\text { External } \\
\text { projections } \\
\text { of cabs }\end{array}$ & 92/114/EEC & - & & & & $x$ & $x$ & $x$ & & & & \\
\hline 50 & Couplings & 94/20/EC & ECE R 55 & $x$ & $x$ & $x$ & $x$ & $x$ & $x$ & $x$ & $x$ & $x$ & $x$ \\
\hline 51 & Flammability & 95/28/EEC & - & & & $x$ & & & & & & & \\
\hline
\end{tabular}




\begin{tabular}{|c|c|c|c|c|c|c|c|c|c|c|c|c|c|}
\hline 52 & $\begin{array}{l}\text { Buses and } \\
\text { coaches }\end{array}$ & 2001/85/EC & ECE R 66 & & $x$ & $X$ & & & & & & & \\
\hline 53 & Front impact & 96/79/EC & - & $x$ & & & & & & & & & \\
\hline 54 & Side impact & 96/27/EC & - & $x$ & & & $x$ & & & & & & \\
\hline 55 & $\begin{array}{l}\text { Vehicles intended } \\
\text { for the transport } \\
\text { of dangerous } \\
\text { goods }\end{array}$ & 98/91/EC & - & & & & $X$ & $x$ & $x$ & $x$ & $X$ & $x$ & $X$ \\
\hline 56 & $\begin{array}{l}\text { Front under } \\
\text { run protection }\end{array}$ & 2000/40/EC & ECE R 93 & & & & & $x$ & $x$ & & & & \\
\hline 57 & $\begin{array}{l}\text { Pedestrian } \\
\text { protection }\end{array}$ & 2003/102/EC & - & $x$ & & & & $x$ & & & & & \\
\hline
\end{tabular}

\section{CONCLUSION}

The Slovenian Traffic Safety Agency plays an important role in procedures regarding motor vehicles. The Slovenian Traffic Safety Agency is closer to organizations which carry out all procedures connected to vehicles, and so it has better overview of all procedures.

The Ministry of Infrastructure and Spatial Planning is legislature for the area of motor vehicles.

The Slovenian Traffic Safety Agency is included in the legislative procedures, so it gives advices and helps with proposals. On European level there are three framework directives for motor vehicles and their trailers, agricultural or forestry tractors, their trailers and interchangeable towed machinery and two or three-wheel motor vehicles. All three framework directives are harmonized so must be implemented in legislation of separate country. There are also directives regarding systems, components and separate technical units and regulations issued by the United Nation's Economic Commission for Europe $[09,08]$. Some of the requirements are not harmonized which means that they have to be put into national legislation. All requirements are connected to road safety and environmental friendliness.

\section{REFERENCES}

1) Derek J., Tršelič J., Svetina T. (2009): TYPE APPROVAL AUTHORITY MEETING; Meeting of authority organizations; Brdo - center, Slovenia.

2) http://www.mzip.gov.si/fileadmin/mzip.gov. si/pageuploads/DPR/MOTORNA_VOZILA /Predpisi/PRAVIL_ES-HOM-_2-3_-_NPB_ 4.pdf.
3) http://www.mzip.gov.si/fileadmin/mzip.gov. si/pageuploads/DPR/MOTORNA_VOZILA /Predpisi/Pravilnik_o_ES_homologaciji_ in_posamicni_odobritvi_motornih_vozil__NPB_1.pdf.

4) http://www.mzip.gov.si/fileadmin/mzip.gov. si/pageuploads/DPR/MOTORNA_VOZILA /Predpisi/Pravilnik_o_ugotavljanju_skladosti_vozil_-_NPB_1.pdf.

5) http://www.mzip.gov.si/si/delovna_podrocja/promet/prometna_politika/vozila/seznam _tehnicnih_specifikacij_za_motorna_in_priklopna_vozila_z_najmanj_stirimi_kolesi_ter _enakovredni_predpisi/

6) http://www.uradni-list.si/1content?id=101428

7) http://www.uradni-list.si/1 content?id=104305

8) Pavić N., Popović V., Vasić M.: DRIVERS AGE AS THE DOMINANT DEMOGRAPHIC FACTOR IN TRAFFIC ACCIDENT, Journal of Applied Engineering Science, 9(2011)3, p.411-416.

9) Popović, V., Damjanović, M., Blagojević, I., Simović, S., (2011) Technical Regulations and Conditions for Importing Passenger Vehicles on the Territory of Southeast Europe, FME Transactions, 39 (3), 105-116.

10) Svetina T. (2005): TYPE APPROVAL AUTHORITY MEETING; Meeting of authority organizations; Madrid, Spain

11) Svetina T. (2007): TYPE APPROVAL AUTHORITY MEETING; Meeting of authority organizations; Zoetermeer, Holland.

Paper sent to revision: 31.05.2012.

Paper ready for publication: 20.06.2012 